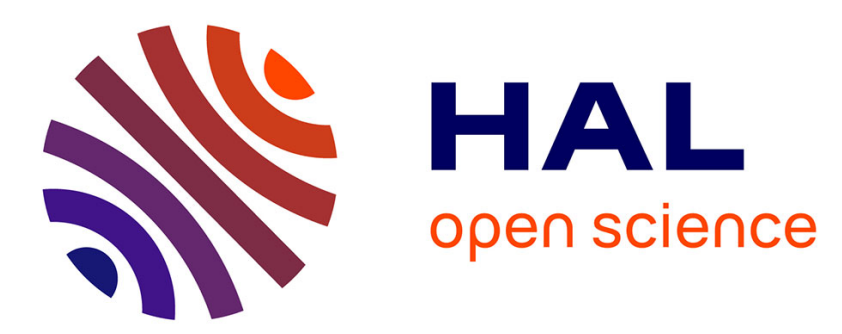

\title{
Implication of phylogenetic systematics of rodent-borne hantaviruses allows understanding of their distribution
}

\author{
Vincent Herbreteau, Jean-Paul Gonzalez, Jean-Pierre Hugot
}

\section{To cite this version:}

Vincent Herbreteau, Jean-Paul Gonzalez, Jean-Pierre Hugot. Implication of phylogenetic systematics of rodent-borne hantaviruses allows understanding of their distribution. Annals of the New York Academy of Sciences, 2006, 1081, pp.39-56. 10.1196/annals.1373.004 . ird-00714427

\section{HAL Id: ird-00714427 \\ https://hal.ird.fr/ird-00714427}

Submitted on 4 Jul 2012

HAL is a multi-disciplinary open access archive for the deposit and dissemination of scientific research documents, whether they are published or not. The documents may come from teaching and research institutions in France or abroad, or from public or private research centers.
L'archive ouverte pluridisciplinaire HAL, est destinée au dépôt et à la diffusion de documents scientifiques de niveau recherche, publiés ou non, émanant des établissements d'enseignement et de recherche français ou étrangers, des laboratoires publics ou privés. 


\section{Implication of Phylogenetic Systematics of Rodent-Borne}

\section{Hantaviruses Allows Understanding of their Distribution}

Vincent HERBRETEAU, ${ }^{\mathrm{a}}$ Jean-Paul GONZALEZ, ${ }^{\mathrm{b}}$ and Jean-Pierre HUGOT ${ }^{\mathrm{a}, \mathrm{b}}$

${ }^{a}$ Institut de Recherche pour le Développement (IRD), 75231 Paris Cedex 05,

France

${ }^{b}$ Muséum National d'Histoire Naturelle, Département Systématique et

Évolution, UMR Origin, Structure and Evolution of Biodiversity, 75231, Paris

cedex 05, France.

KEYWORDS: rodent-borne hantaviruses, Thottapalayam, S gene, phylogeny, Bayesian analysis, biogeography, coevolution 


\begin{abstract}
Hantaviruses' distribution is reassessed after performing a cladistic analysis on ninety-three strains isolated from rodents, and one used as outgroup: Thottapalayam isolated from a shrew. While most hantaviruses found in wild animals were collected in Northern Asia, Europe, North America and South America, only Thottapalayam and Thailand were found in South and Southeastern Asia. Thottapalayam is highly divergent from the other known hantaviruses and may represent the emerging tip of a different lineage. Serological surveys carried out to detect evidence of Hantavirus in human populations revealed positive samples in West and Central Africa but also in Thailand with a first case recently confirmed. This suggests that Hantaanrelated viruses may infect humans out of their well-documented range. Thus, if rodents are probably the primary reservoir, other mammals may be involved in the cycle of hantaviruses. Additional work is needed out of the traditional areas where hantaviruses have been recorded. New viruses, different hosts and different human syndromes, may be discovered in the future mainly in Southeastern Asia and in Africa where murine rodents are present and highly diversified.
\end{abstract}




\section{INTRODUCTION}

Wild rodents are the usual reservoirs of the zoonotically important hantaviruses (genus Hantavirus, family Bunyaviridae). Several serologically distinct groups have been associated with different syndromes. In the Old World, Hantaan, Dobrava, Seoul and Puumala cause the clinical forms of hemorrhagic fever with renal syndrome) $(\mathrm{HFRS})^{1}$. In the New World, Sin Nombre and Andes are responsible for hantavirus pulmonary syndrome (HPS) $)^{2}$ A last group, Tula, widely distributed in Russia and Eastern Europe has never been associated with a human disease.

The hantavirus genome has 3 segments; large (L 6,5 kb), medium (M 3,7 kb) and small (S 1,8 kb) encoding: viral transcriptase-replicase, surface glycoprotein precursor (G1 and G2) and nucleocapsid protein respectively., Different analyses based on the alignment of the $M$ or $S$ sequences. $^{1,5,6,7,8,9,10,11,12,13,14}$ have been performed and used to discuss the distribution of these viruses, relative to the biogeography and evolutionary history of their hosts. Murine rodents are the primary hosts and, because each virus group seems to be associated with a particular rodent group, the hypothesis of coevolution has been suggested. ${ }^{1,3,5,6}$ Since the methodology to establish such coevolution has been questioned and no firm conclusions have been reached, this paper revisits the coevolution of the virus by examining the evolutionary relationship of the $S$ genes of various hantaviruses to their respective murine hosts. 


\section{MATERIALS AND METHODS}

\section{Sequences and alignment}

The data set includes Hantavirus S sequences, from 94 taxa, found in GenBank (Table 1): 92 isolated from different rodent hosts, one isolated in Korea from a bat (Kim, direct submission 1995) and Thottapalayam detected in India from a shrew (Suncus murinus) by Carey et al., ${ }^{16}$ identified by Xiao et al. ${ }^{17}$ and recently introduced (complete $S$ sequence) in GenBank by Schmaljohn and Toney (direct submission, 2004). Only complete CDS, whose wild host was certainly identified, were considered. The S sequence of Dugbe virus previously used as outgroup by Hughes and Friedman, ${ }^{11}$ was first considered but finally excluded as explained in the outgroup paragraph. A virus described in Thailand from a Bandicota indica ${ }^{1}$ could not be included in the data set because the $\mathrm{S}$ sequence of this virus remains unknown. Selected sequences range between 1,130 and 2,082 nucleotides from which: first 42 correspond to the primer and nucleotides; $1,342-2,082$ to the codon stop and non-coding region. Alignment of the coding part (nucleotides 43 to 1,341) was performed using CLUSTAL-X automatic procedure, ${ }^{18}$ then improved manually using SE-AL v2.0a11 ${ }^{19}$ and validated using the amino acid translation. When applied to the non-coding part, the same procedure made visible the impossibility to detect real homologies between most of the sequences. Thus, only the coding part of the gene was used for phylogenetic analyses. Sequences were analyzed at nucleotide level. 


\section{Aligning and coding indels}

Sequence alignment made necessary to postulate several gaps, particularly between nucleotides 766 and 813 . Various approaches have been employed to deal with insertion-deletions (indels), ranging from their total exclusion to their treatment as missing data or as a fifth character state. Gaps are considered reliable characters by many systematists and the first approach means the loss of potential phylogenetic information. ${ }^{20}$ In addition, in our data set, indels are observed within the hypervariable region where the percentage of parsimony informative characters is superior to $90 \%$ (less than $60 \%$ for the rest of the matrix). Therefore, we kept this region for analysis. Standard procedures for coding gaps suffer of several weaknesses: either the different sites are analyzed independently (gap = new state) and each gap is artificially over weighted relatively to the number of sites, or each site is coded "?" (gap $=$ missing data) and optimization procedure makes the whole zone devoid of phylogenetic information. To express potential phylogenetic information contained in zones with internested insertions/deletions and substitutions, 8 characters coding the presence/absence of deletions between nucleotides 766 and 813 were added. Finally, the matrix includes 1,323 RNA characters and 8 presence/absence characters.

\section{Outgroup rooting}

An outgroup sequence must be closely related to the rest of the sequences, but comparatively more different than the others are between themselves. The 
introduction of the Thottapalayam sequence within the previously aligned rodent-borne sequences: makes necessary the addition of several deletions; shows that, Thottapalayam possesses several conservative parts of the rodentborne sequences. Thus, if Thottapalayam may certainly be considered a Hantavirus, it is highly divergent from other members of the genus. This is confirmed by the values of the total-character distances calculated using PAUP: within the rodent-borne group, distances vary from 2 to 516; between Thottapalayam and the others, distances range between 765 and 859 . Thus Thottapalayam may be considered a valuable outgroup and was included in the data set.

\section{Sequence analyses}

Two methods likely to give results interpretable in an evolutionary context were used: maximum parsimony analysis (MP) and Bayesian analysis (MB). MACClAde $4.0^{21}$ and TREeVIEW $1.3^{22}$ were used for data and tree handling and for computation of statistics. MP analysis was computed using PAUP* $4.0 \mathrm{~b} 10 .^{23}$ Robustness of nodes was assessed using bootstrap method ${ }^{24}$ computed after 10,000 replicates of heuristic search with closest stepwise addition of taxa. MoDELTEST 3.0 ${ }^{25}$ was used to determine the best fitting likelihood settings: the general time reversible model ${ }^{26}$ with among-site substitution rate heterogeneity described by a gamma distribution with eight categories ${ }^{27}$ and a fraction of sites (INV) constrained to be invariable (GTR+I+G, selected by AIC). MB analysis using these settings was performed 
using MrBayes v3.0B4 ${ }^{28}$ Bayesian approach allows defining an explicit probability model of character evolution and obtaining a rapid approximation of posterior probabilities of trees, through the use of the Markov Chain Monte Carlo (MCMC) approach. MrBayes also allows performing phylogenetic analyses of data sets combining information from different subsets, evolving under different evolutionary models. Two partitions were distinguished in our original data set: partition $1=$ nucleotide (characters 1-1,323) for which the likelihood model chosen was the GTR $+\mathrm{I}+\mathrm{G}$; partition 2=indels (characters 1,324-1,331) treated as presence/absence. Analysis was conducted with four independent Markov chains, run for 2,000,000 metropolis-coupled MCMC generations, with tree sampling every 10 generations and burn-in after 3,300 trees. Consensus tree was computed using the "halfcompat" option, equivalent of $50 \%$ majority rule. Proportion values of posterior probability of bipartition, considered equivalent to bootstrap values ${ }^{29,30}$ were used for evaluation of robustness of the nodes.

\section{Virus taxonomy}

In the following and in the figures:

- Virus species listed in the Eighth Report of the International Committee on Taxonomy of Viruses ${ }^{31}$ are in italic script.

- Strain names are in roman script, or are represented using their abbreviation in caps when an abbreviation has been proposed.

- When different strains of a same virus species are included, a number 
or an adjective (generally dealing with the geographic origin) is added.

The correspondence between the virus species, strain names and abbreviations is given in Table 1.

\section{RESULTS}

\section{General}

MP or MB analyses yield consistent results. All bipartitions found by MP analysis with a bootstrap value superior or equal to $95 \%$ were also found by MB analysis with a posterior probability equal or superior to $95 \%$. In addition, $\mathrm{MB}$ analysis gave a resolution and a support superior or equal to $50 \%$ for several nodes, which were unresolved, or resolved with a bootstrap inferior to $50 \%$, in the MP analysis. Even if MB analysis is likely to favor higher values when compared to bootstrap analysis, ${ }^{28,29,30}$ the results are fully congruent and are represented on Figure 1. Figures 2 and 3 detail the composition of the 3 main clades.

The cladogram is rooted between a basal branch corresponding with Thottapalayam and a monophyletic group including all the rodent-borne parasites, distributed following 3 main clades: CLADE-1 includes "Seoul, Hantaan, Dobrava"; CLADE-2 and CLADE-3 are sister clades including: "Bayou, Sinnombre, Andes", and "Islavista, Tula, Puumala", respectively. Each clade and the sister-grouping of CLADE-2 and CLADE-3, have a support superior or equal to $78 \%$. CLADE- 1 groups 22 taxa: all the viruses hosted by 
Murinae rodents, and the single strain found on a bat; CLADE-2 groups 23 taxa: all the viruses hosted by Sigmodontinae rodents; CLADE-3, groups 48 taxa: all the viruses hosted by Arvicolinae rodents. Regarding the geographic distribution: $C L A D E-1$ is exclusively Palearctic, except Tchoupitoulas collected in the Nearctic (Louisiana); CLADE-2 is found exclusively in the New World and associates strains from the Nearctic and Neotropics; CLADE-3 may be divided into one Nearctic subclade (Islavista) and the sister-grouping of 2 Palearctic subclades (Tula + Puumala) .

\section{CLADE-1: "Seoul, Hantaan, Dobrava" (Figure 2).}

Viruses hosted by Rattus spp. are distinguished from those hosted by Niviventer confucianus and Apodemus spp. With the exception of the parasite of Niviventer (considered by taxonomists closer from Rattus) this distribution matches the taxonomy of the rodents at genus level. However, different virus strains hosted by the same rodent species are not grouped together. The bat virus is included in Hantaan; its closer relative is HT.76118. Regarding the geographic distribution: Seoul is found in eastern China, with the exception of Sapporo (Japan) and Tchoupitoulas (Louisiana), which are sister-taxa. Hantaan also is restricted to the eastern part of the Palearctic region, but with a wider distribution including several provinces in China, Korea and the Amur area (Northeastern Siberia). Dobrava has a European distribution extending

from Estonia toward Greece, through Western Russia, Slovakia and Bosnia. 
The arrangement of Dobrava viruses on the cladogram generally fit with a North to South distribution.

\section{CLADE-2: “Bayou, Sinnombre, Andes” (Figure 2).}

From the three subclades two are hosted by Sigmondontini rodents (Bayou, Andes), while Neotomini rodents host Sinnombre. Bayou, found in 3 states of Southeastern North America (Florida, Louisiana and Texas) is hosted by two different genera, Oryzomys and Sigmodon. Sinnombre is subdivided into: a group of three taxa found in Arizona, New Mexico, Costa Rica and hosted by Peromyscus sp. and Reithrodontomys spp.; a group hosted by Peromyscus spp. ranging from Northeastern to Southwestern and Central United States. Andes, is entirely found in the Neotropics and hosted by Sigmodontini rodents: Oligoryzomys is the most frequent, together with several other genera (Akodon, Bolomys, Calomys, Sigmodon). The most divergent species in this group is Caño Delgadito from Venezuela; the other species are arranged following their geographic origin: Laguna Negra and Rio Marmore (Bolivia and Paraguay); Andes-Chile 1 and 2, (Chile); the last seven ones from Northern Argentina. Distribution of virus taxa within CLADE-2 generally fits with the taxonomy of rodents at host tribe level and a dominant genus may be recognized for each of the main subgroups. However: the Sigmodontini parasites are not monophyletic; as in CLADE-1, no congruence is observed at host species level (closely related viruses hosted by different host species, viruses hosted by a same host species not closely related on the cladogram). 


\section{ClaDE-3: "Prairie, Tula, Puumala" (Figure 3).}

CLADE-3 is the sister group of CLADE-2 and is hosted by Arvicolinae rodents. Tula and Puumala are strictly Palearctic, Islavista is strictly Nearctic. Microtus spp. is the dominant hosts for Islavista and Tula. Islavista may be subdivided in two groups: Isla Vista 1, 2, 3 are Californian, Prairie Vole and Prospect Hill 1 and 2 are from South Central United States. Tula has a European distribution extending North to South, from Poland, Germany, Moravia, Western Russia and Slovakia. In Puumala: Microtus, associated with Lemnus, is present in a small basal group including three virus species found in the extreme East of Russian Siberia (Vladivostok, Khabarovsk and Topografov), the other species are hosted by Clethrionomys rufocanus or $C$.

glareolus. Parasites of C. rufocanus are Japanese. Parasites of C. glareolus have a distribution extending from Northwestern Europe (Denmark, Belgium) to Scandinavia, Finland and South Central Russia. In Puumala a dominant host species may be recognized for each of the main subgroups. But, in Islavista and Tula there is no general congruence between the virus and host classifications at the species level: closely related viruses hosted by different host species; viruses hosted by a same host species, not closely related on the cladogram. 


\section{DISCUSSION}

Clades, groups, robustness of the nodes and molecular data.

Our analysis confirms the 3 main clades previously described within the hantaviruses ${ }^{6,11}$ and supports the subdivision of each clade into 3 subclades. "Seoul”, “Hantaan”, “Dobrava”, “Andes”, “Tula”, "Puumala," already have been named. We propose new names for several new groups: "Bayou", including Bayou, Black Creek, Muleshoe; "Sinnombre", including: Sin Nombre, Convict, Monongahela, New York and Limestone, El Moro, Rio Segundo; "IslaVista", including: Prairie Vole, Prospect Hill, Isla Vista. The support for corresponding nodes of the cladogram is generally between 80 and 100. The alignment shows that main clades and subclades are supported by amino acid changes caused by synonymous or non-synonymous nucleotide differences. Most changes occur in a hypervariable (HV) region identified by several previous studies ${ }^{32,33}$. Hughes and Friedman ${ }^{11}$ defined the HV region as residues 242-281. In our alignment, HV region corresponds to amino acid residues $249-317$ and includes $92 \%$ of informative sites $(62 \%$ in whole matrix). This region also includes several regular indels corresponding with the main subdivisions of the cladogram.

\section{Host specificity and correspondence with host taxonomy}

The topology of the 3 main clades matches the phylogeny of the 3 host subfamilies to which they are respectively devolved. Dominant host genera 
(pointed by arrows on Figure 1) may be recognized by mapping the host genus, as a character, on the cladogram of the virus. Within CLADE-1, Rattus is dominant for Seoul, Apodemus for the association Hantaan-Dobrava. Within CLADE-2, each subclade is linked to a particular host tribe (Neotomini or Sigmodontini); Sigmodon appears as a potential primitive host; Peromyscus and Oligorizomys are the dominant host genera for Sinnombre and Andes, respectively. Within CLADE-3, Microtus appears as a primitive host genus, and Clethrionomys is the dominant host genus for the Puumala subclade. The good correspondence of the phylogenies at their highest level is consistent with the hypothesis of coevolution: the Hantavirus and the Muridae may have evolved and dispersed in parallel. But, whatever the clade considered, there is a mismatch of the host and parasite distributions at species level. This looks like if host specificity disappeared somewhere between the species and/or genus level. Depending which clade is considered, this limit is variable: host switching at genus level appears difficult and unlikely within CLADE-1 and CLADE-3, and easier in CLADE-2; within CLADE-2 the highest diversity, thus weakest specificity at genus level, is observed in Andes.

\section{Biogeography of rodent-borne hantaviruses}

CLADE-1 is Palearctic except Tchoupitoulas, reported from a wild Rattus norvegicus in New Orleans. $R$. norvegicus is a cosmopolitan species, which dependence for human quarters is well known and the presence of this Hantavirus in the New World may probably be, interpreted a case of 
dispersion by humans. CLADE-2 is exclusively found in the New World: Figure 2 shows that, unexpectedly following the hypothesis of coevolution, the parasites of the Nearctic Sigmodontini (Bayou) are not closely related to the parasites of Neotropical Sigmodontini (Andes). Most of the Sigmodontini biodiversity is found in the Neotropics while their sister group, the Neotomini, is dominant in North America. Bayou seems limited to Southeastern United States, and may perhaps be interpreted resulting of an ancient isolation of its hosts in a remote part of their range. CLADE-3 has a mixed distribution with one small Nearctic subclade (Isla Vista) and 2 Palearctic subclades (Tula, Puumala). Prairie and Tula are hosted by different species of genus Microtus, as are Vladivostok and Khabarovsk which are the sister group of Puumala (hosted by Clethrionomys spp.). This distribution is consistent with a Palearctic origin, a passage into the New World probably transported by the Arvicolinae (Microtus looks a good candidate), a later dispersion in North and South America following the migrations of the Sigmodontinae. This scenario mimics the scenario generally accepted for the radiation of the Muridae starting from their South Asian center of origin and is compatible with the hypothesis of a parallel evolution. Within the subclades a different pattern is suggested, because transmission between different rodent species in a same genus (and between different genera in the Neotropics) looks possible. 


\section{CONCLUSION}

Two different patterns of dispersion are explaining the evolution of the hantaviruses: the first one, characterized by a strong specificity for a particular group of hosts, explains the ancient history of this group and its coevolution with the Muridae; the second one, characterized by a slack specificity, is corresponding with the recent and current history of the viruses and their opportunistic circulation by using contacts between closely related rodent genera, species and/or populations. This second pattern explains why, when the distribution of the hosts and parasites is enough documented (Dobrava, Tula, Puumala, Andes), a geographic gradient become visible. Different pattern, following different specificity is in agreement with what is known about Hantavirus survival outside their hosts. Sauvage et al. ${ }^{34}$ considering the role of indirect transmission on virus persistence, suggest that viruses remain active outside the host, which could permit transmission without physical contact with the infectious rodents. This explains how hantaviruses may switch when the specific barrier is low and when different hosts have overlapping territories.

While most Bunyaviridae are hosted by arthropods, hantaviruses have rodents as principal hosts. However, 2 strains have been isolated from non-rodent mammals: Thottapalayam, isolated from a shrew; the Hantaan virus isolated from a bat. Considering its strong differences with the other hantaviruses, Thottapalayam cannot be interpreted resulting from a recent host switching 
between a rodent and a shrew. Further investigations are needed to decide if this adaptation to a different group of mammals is an exception, or may represent the emerging tip of a different lineage.

The bat virus is included in Hantaan; its closer relative is HT.7611. No significant difference of branch length is observed between the two strains and their Total-character distance equals 4; this suggests that the two sequences are almost identical: thus, the presence of a Hantavirus in $R$. ferrumequinum must probably be interpreted as the result of an horizontal transfer.

Most of hantaviruses found in wild animals were collected in the Holarctic, or the Neotropics (Northern Asia, Europe, North America, and South America). But, Thottapalayam comes from South Asia, where is also found Thailand, hosted by Bandicota indica, a Muridae rodent. Serological surveys carried out to detect evidence of Hantavirus infection in human populations revealed that: in Thailand, in different provinces and/or in different environments, $1,2 \%$ to $31,4 \%$ of individual tested had Hantavirus antibody ${ }^{35,36,37}$; the recent publication of the first human case in Thailand ${ }^{38}$ confirms the presence of Hantavirus in South Asia; also, screenings performed in West and Central Africa where a human case has not yet been reported, show that humans may have been infected by Hantaan-related virus ${ }^{39}$. All this suggests that, if rodents are probably the primary reservoir, other mammals may be involved in the cycle of hantaviruses; new viruses, different hosts and different human syndromes may be expected to be discovered in the future. Additional work is 
needed out of the traditional areas where Hantaviruses have been recorded, mainly in Southeastern Asia and in Africa where Muridae rodents are present and highly diversified.

\section{REFERENCES}

01. Schmaljohn, C. A., A. Schmaljohn, and J. Dalrymple. 1987. Hantaan virus M RNA: coding strategy, nucleotide sequence, and gene order. Virology 157:31-39.

02. Childs, J. E., T. G. Ksiazek, C. F. Spiropoulou, J. W. Krebs, S. Morzunov, G. O. Maupin, K. L. Gage, P. E. Rollin, J. Sarisky, R. E. Enscore, J. K. Frey, C. J. Peters, and S. T. Nichol. 1994. Serologic and genetic identification of Peromyscus maniculatus as the primary rodent reservoir for a new hantavirus in the southwestern United States. J. Infect. Dis. 169:1271-1280.

03. Schmaljohn, C., G. Jennings, J. Hay, and J. M. Dalrymple. 1986. Coding strategy of the S-genome segment of Hantaan virus. Virology 155:633643.

04. Elliot, R. M., C. S. Schmaljohn, and M. S. Collett. 1991. Bunyaviridae genome structure and gene expression. Curr. Top. Microbiol. Immunol. 69:91-141.

05. Dekonenko, A., V. Yakimenko, A. Ivanov, V. Morozov, P. Nikitin, S. Khasanova, T. Dzagurov, E. Tkachenko, and C. Schmaljohn. 2003. 
Genetic similarity of Puumala viruses found in Finland and western Siberia and of the mitochondrial DNA of their rodent hosts suggests a common evolutionary origin. Infect. Gen. Evol. 3:245-257.

06. Nichol, S.T. 1999. Genetic analysis of Hantaviruses and their host relationships. In: Saluzzo JF, Dodet B, eds. Factors in the emergence and control of rodent-borne viral diseases. Paris, France: Elsevier SAS:99109.

07. Monroe, M. C., S. P. Morzunov, A. M. Johnson, M. D. Bowen, H. Artsob, T. Yates, C. J. Peters, P. E. Rollin, T. G. Ksiazek, and S. T. Nichol. 1999. Genetic Diversity and Distribution of Peromyscus-Borne Hantaviruses in North America. Emerg. Infect. Dis. 5:75-86.

08. Heisk,e A., B. Anheier, J. Pilaski, V. E. Volchkov, and H. Feldmann. 1999. A new Clethrionomys-derived Hantavirus from Germany: evidence for distinct genetic sublineages of Puumala viruses in Western Europe. Virus Res. 61:101-112.

09. Hjelle, B., F. Chavez-Giles, N. Torrez-Martinez, T. Yates, J. Sarlisky, J. Webb, and M. Ascher. 1994. Genetic identification of a novel Hantavirus of the harvest mouse Reithrodontomys megalotis. J. Virol. 68:6751-6754.

10. Horling, J., V. Chizhikov, A. Lundkvist, M. Jonsson, L. Ivanon L, A. Dekonenko, B. Niklasson, T. Dzagurova, C. J. Peters, E. Tkachenko, and S. Nichol. 1996. Khabarovsk virus: a phylogenetically and serologically 
distinct Hantavirus isolated from Microtus fortis trapped in far-east Russia. J. Gen. Virol. 77:687-694.

11. Hughes, A. L., and R. Friedman. 2000. Evolutionary diversification of protein-coding genes of Hantaviruses. Mol. Biol. Evol. 17:1558-1568.

12. Kariwa, H., K. Yoshimatsu, and J. Sawabe. 1999. Genetic diversities of Hantaviruses among rodents in Hokkaido, Japan and Far East Russia. Virus. Res. 59:219-228.

13. Levis, S., S. P. Morzunov, J. E. Rowe, D. Enria, N. Pini, G. Calderon, M. Sabattini, and S. C. St. Jeor. 1998. Genetic diversity and epidemiology of Hantaviruses in Argentina. J. Infect. Dis. 177:529-538.

14. Lopez, N., P. Padula, C. Rossi, S. Miguel, A. Edelstein, E. Ramirez E, and M. T. France-Fernandez. 1997. Genetic characterization and phylogeny of Andes virus and variants from Argentina and Chile. Virus Res. 50:77-84.

15. Li, W.-H. 1997. Molecular Evolution. Sinauer As., Sunderland, MA.

16. Carey, D,, R. Reuben, K. Panicker, R. Shope, and R. Myers. 1971. Thottapalayam virus: a presumptive arbovirus isolated from a shrew in India. Indian J. Med. Res. 59:1758-60.

17. Xiao, S.-Y., J. W. Leduc, Y. K. Chu, and C. S. Schmaljohn. 1994. Phylogenetic analyses of virus isolates in the genus Hantavirus, family Bunyaviridae. Virology 198:205-217. 
18. Thompson, J. D., D. G. Higgins, and T. J. Gibson. 1994. CLUSTAL W: improving the sensitivity of progressive multiple sequence alignment through sequence weighting, position- specific gap penalties and weight matrix choice. Nucleic Acids Res. 22:4673-4680.

19. Rambaut, A. Se-Al. Sequence Alignment Editor. Ver. 1.0 alpha 1. 1996. University of Oxford, Oxford, U.K.

20. Barriel, V. 1994. Phylogénies moléculaires et insertions-délétions de nucléotides. CR Acad Sci Sér III 317:693-701.

21. Maddison, D. R. W., and P. Maddison. MacClade 4: Analysis of phylogeny and character evolution. Version 4.0. 2000 Sinauer Associates, Sunderland, Massachusetts.

22. Page, R. D. M. 1996. TreeView: An application to display phylogenetic trees on personal computers. Comp. Appl. Bios. 12:357-358.

23. Swofford, D. L. PAUP*. Phylogenetic Analysis Using Parsimony (and Other Methods). Version 4. 0b10 2001 Sinauer Associates, Sunderland, Massachusetts.

24. Felsenstein, J. 1985. Confidence limits on phylogenies: an approach using the bootstrap. Evolution 39:783-791.

25. Posada, D., and K. A. Crandall. 1998. Modeltest: testing the model of DNA substitution. Bioinformatics 14:817-818. 
26. Yang Z. 1994. Estimating the pattern of nucleotide substitution. J. Mol. Evol. 39:105-111.

27. Yang Z. 1996. Among-site rate variation and its impact on phylogenetic analyses. Trends Ecol. Evol. 11:367-372.

28. Huelsenbeck, J. P., and F. Ronquist. 2001. MRBAYES: Bayesian inference of phylogeny. Bioinformatics 17:754-755.

29. Cummings, M. P.,S. A. Handley, D. S. Myers, D. L. Reed, A. Rokas, and K. Winka. 2003. Comparing Bootstrap and Posterior Probability Values in the Four-Taxon Case. Syst. Biol. 52:477-487.

30. Zhaxybayeva, O., and J. P. Gogarten. 2002. Bootstrap, Bayesian probability and maximum likelihood mapping: exploring new tools for comparative genome analyses. BMC Genomics 3:1-15.

31. Nichols S.T., Beaty B.J., Elliott R.M., Goldbach R., Plyusnin A., Schmaljohn C.S. and Tesh R.B. (2006). Family Buyaviridae. In: Eight Report of the International Committee on Taxonomy of Viruses. Eds C. Fauquet, M. Mayo, J. Maniloff, U. Desselberger, L. A. Ball. Elsevier/Academic Press.

32. Lundkvist, A., H. Kallio-Kokko, K. B. Sjölander, H. Lankinen, B. Niklasson, A. Vaheri, and O. Vapalahti. 1996. Characterization of Puumala virus nucleocapsid protein : identification of B-cell epitopes. Virology 216:397-406. 
33. Plyusnin, A., O. Vapalahti, and A. Vaheri. 1996. Hantaviruses: genome structure, expression and evolution. J. Gen. Virol. 77:2677-2687.

34. Sauvage, F., M. Langlais, N. G. Yoccoz, and D. Pontier. 2003. Modelling Hantavirus in fluctuating populations of bank voles: the role of indirect transmission on virus persistence. Journal of Animal Ecology 72:1-13.

35. Elwell, M. R., G. S. Ward, M. Tingpalapong, J. W. Leduc. 1985. Serologic evidence of Hantaan-like virus in rodents and man in Thailand. Southeast Asian J. trop. Med. Public Health 16:349-354.

36. Nitatpattana, N., G. Chauvency, J. Dardaine, T. Poblap, K. Jumronsawat, W. Tangkanakul, D. Poonsuksombat, S. Yoksan, and J.-P. Gonzalez. 2000. Serological study of Hantavirus in the rodent population of Nakhon Pathom and Nakhon Ratchasima provinces in Thailand. Southeast Asian J. Trop. Med. Public Health 31:277-282.

37. Sawasdikol, S., M. Tamura, and P. Jamjit. 1989. Antibody to hemoragic fever with renal syndrome in man and rat in Thailand. Bull. Dept. Med. Sci. 31:125-130.

38. Suputtamongkol Y, Nitatpattana N., Chyakulkeree M, Palabodeewat S., S Yoksan, \& JP Gonzalez, 2005. Hantavirus infection in Thailand: first clinical case report. Southern Asian J Trop. Med. \& Pub. Health, $36,1: 217-220$. 
39. Gonzalez, J.-P., J. B. McCormick, D. Baudon, J. P. Gautun, D. Y. Meunier, E. Dournon, and A. J. Georges. 1984. Serological evidence for hantaan-related virus in Africa. The Lancet 324:1036-1037. 


\section{FIGURE CAPTIONS}

FIGURE 1. Cladogram resulting of Bayesian analysis using GTR+I+G model. Names given to the main groups according to previous publications, except "Bayou" and "Islavista" which are proposed as new names. Different color patterns are attributed to different geographic areas. Arrows point out optimization of the host genera on the cladogram.

FIGURE 2. Detail of CLADE-1 and CLADE-2 of Figure 1. Posterior probability numbered when inferior to $95 \%$ (probability of no numbered nodes between 95 and 100). For each virus strain the scientific name of the host is given; different color patterns are attributed to different host groups and to different biogeographic areas. Abbreviation: Reith. $=$ Reithrodontomys. Oligo. $=$ Oligorizomys.

FIGURE 3. Detail of CLADE-3 of Figure 1. See legend of Figure 2. 
TABLE 1. List of Hantavirus strains included in present study. First two columns: name of strain and acronym used in text and figures. Columns 3 and 4: scientific and Family names of principal host. Columns 5 and 6: accession number of sequence and number of nucleotides given in Genbank. Region refers to biogeographic areas: Palearctic (PAL), Nearctic (NEA), Neotropical (NEO), Oriental (ORIENT). Column 7: in which country, and when possible in which province or locality, virus strain has been collected.

\begin{tabular}{|c|c|c|c|c|c|c|c|c|}
\hline & Virus species \& strain & Abbreviation & Host species & Family & Accession nb & Nucl & Region & Distribution \\
\hline 1 & Dobrava-Estonia & DOBV-Estonia1 & Apodemus agrarius & Murinae & AJ009773 & 1671 & PAL & Estonia (Saaremaa) \\
\hline 2 & Dobrava-Estonia & DOBV-Estonia2 & Apodemus agrarius & Murinae & AJ009775 & 1671 & PAL & Estonia (Saaremaa) \\
\hline 3 & Dobrava-Slovakia & DOBV-Slovakia1 & Apodemus agrarius & Murinae & AJ269549 & 1704 & PAL & Slovakia (Kosice) \\
\hline 4 & Dobrava-Bosnia & DOBV-Bosnia & Apodemus flavicollis & Murinae & L41916 & 1670 & PAL & Bosnia \\
\hline 5 & Dobrava-Greece & DOBV-Greece1 & Apodemus flavicollis & Murinae & AJ410615 & 1290 & PAL & Greece (Northeast) \\
\hline 6 & Dobrava-Greece & DOBV-Greece2 & Apodemus flavicollis & Murinae & AJ410619 & 1290 & PAL & Greece (Northeast) \\
\hline 7 & Dobrava-Russia & DOBV-Russia1 & Apodemus sylvaticus & Murinae & AF442623 & 1637 & PAL & Russia (Krasnodar) \\
\hline 8 & Dobrava-Russia & DOBV-Russia2 & Apodemus sylvaticus & Murinae & AF442622 & 1196 & PAL & Russia (Goryachiy) \\
\hline 9 & Dobrava-Slovakia & DOBV-Slovakia2 & Apodemus sylvaticus & Murinae & AJ269550 & 1704 & PAL & Slovakia (Kosice) \\
\hline 10 & Hantaan-76118 & HTNV-76118 & Apodemus sylvaticus & Murinae & M14626 & 1696 & PAL & South Korea \\
\hline 11 & Hantaan-Maaji & HTNV-Maaji & Apodemus agrarius & Murinae & AF321094 & 1700 & PAL & Korea (Maaji) \\
\hline 12 & Hantaan-Amur AP61 & AMRV.AP61 & Apodemus peninsulae & Murinae & $\mathrm{AB} 071183$ & 1290 & PAL & Russia FE (Solovey) \\
\hline 13 & Hantaan-Amur AP63 & AMRV.AP63 & Apodemus peninsulae & Murinae & AB071184 & 1696 & PAL & Russia FE (Solovey) \\
\hline 14 & Hantaan-Guizhou & HTNV-Guizhou & Apodemus sylvaticus & Murinae & AB027097 & 1635 & PAL & China (Guizhou) \\
\hline 15 & Hantaan-Anhui & HTVN-Anhui & Niviventer confucianus & Murinae & AB027523 & 1654 & PAL & China (Anhui) \\
\hline 16 & Hantaan-Bat & HTNV-Bat & Rhinolophus ferrumequinum & Rinolophidae & U37768 & 1696 & PAL & Korea \\
\hline
\end{tabular}




\begin{tabular}{|c|c|c|c|c|c|c|c|c|}
\hline 17 & Seoul-L99 & SEOV-L99 & Rattus losea & Murinae & AF288299 & 1764 & PAL & China (Jiangxi) \\
\hline 18 & Seoul-Sapporo & SEOV-Sapporo & Rattus norvegicus & Murinae & M34881 & 1769 & PAL & Japan (Sapporo) \\
\hline 19 & Seoul-Shanxi & SEOV-Shanxi & Rattus rattus & Murinae & AF288643 & 1772 & PAL & China (Shanxi) \\
\hline 20 & Seoul-Tchoupitoulas & SEOV-Tchoupi & Rattus rattus & Murinae & AF329389 & 1785 & NEA & USA (Louisiana) \\
\hline 21 & Seoul-Zhejiang & SEOV-1Zhejiang1 & Rattus rattus & Murinae & AB027522 & 1692 & PAL & China (Zhejiang) \\
\hline 22 & Seoul-Zhejiang & SEOV-Zhejiang2 & Rattus rattus & Murinae & AF288653 & 1772 & PAL & China (Zhejiang) \\
\hline 23 & Sin Nombre & SNV & Peromyscus maniculatus & Neotominae & L25784 & 2059 & NEA & USA (S-West \& Centra \\
\hline 24 & SinNombre-Convict Creek & SNV-Conv.74 & Peromyscus maniculatus & Neotominae & L33683 & 1287 & NEA & USA (California) \\
\hline 25 & SinNombre-Convict Creek & SNV-Conv.107 & Peromyscus maniculatus & Neotominae & L33816 & 1287 & NEA & USA (California) \\
\hline 26 & SinNombre-Monongahela & MGLV & Peromyscus maniculatus & Neotominae & U32591 & 2082 & NEA & USA (Appalachian) \\
\hline 27 & NewYork-RI1 & NYork-RI1 & Peromyscus leucopus & Neotominae & U09488 & 2078 & NEA & USA (North East) \\
\hline 28 & Limestone Canyon & Limestone Canyon & Peromyscus boylii & Neotominae & AF307322 & 1209 & NEA & USA (Arizona) \\
\hline 29 & El Moro Canyon & El Moro Canyon & Reithrodontomys megalotis & Neotominae & U11427 & 1896 & NEA & USA (New Mexico) \\
\hline 30 & Rio Segundo & RioSegundo & Reithrodontomys mexicanus & Neotominae & U18100 & 1749 & NEO & Costa Rica \\
\hline 31 & Andes-AH1 & ANDV-AH1 & Oligoryzomys longicaudatus & Sigmodontinae & AF004660 & 1876 & NEO & Argentina \\
\hline 32 & Andes-Bermejo & BMJV & Oligoryzomys chacoensis & Sigmodontinae & AF482713 & 1933 & NEO & Argentina (Oran) \\
\hline 33 & Andes-Chile & ANDV-Chile1 & Oligoryzomys longicaudatus & Sigmodontinae & AF291702 & 1871 & NEO & Chile (Aysen) \\
\hline 34 & Andes-Chile & ANDV-Chile2 & Oligoryzomys longicaudatus & Sigmodontinae & NC003466 & 1871 & NEO & Chile (Aysen) \\
\hline 35 & Andes-Lechiguanas & LECV & Oligoryzomys flavescens & Sigmodontinae & AF482714 & 1938 & NEO & Argentina (Lechiguana) \\
\hline 36 & Andes-Norte & ANDV-Norte & Oligoryzomys chacoensis & Sigmodontinae & AF325966 & 1921 & NEO & Argentina Norte \\
\hline 37 & Andes-Oran & ORNV & Oligoryzomys longicaudatus & Sigmodontinae & AF482715 & 1919 & NEO & Argentina (Oran) \\
\hline 38 & Andes-Pergamino & PRGV & Akodon azarae & Sigmodontinae & AF482717 & 1860 & NEO & Argentina \\
\hline 39 & Maciel & Maciel & Bolomys benefactus & Sigmodontinae & AF482716 & 1869 & NEO & Argentina (Maciel) \\
\hline 40 & Laguna Negra & Laguna Negra & Calomys laucha & Sigmodontinae & AF005727 & 1904 & NEO & Paraguay, Bolivia \\
\hline 41 & Rio Mamore & RioMamore & Oryzomys microtis & Sigmodontinae & U52136 & 1975 & NEO & Bolivia \\
\hline 42 & Bayou & Bayou & Oryzomys palustris & Sigmodontinae & L36929 & 1958 & NEA & USA (Louisiana) \\
\hline 43 & Black Creek Canal & Black Creek & Sigmodon hispidus & Sigmodontinae & L39949 & 1989 & NEA & USA (Florida) \\
\hline 44 & Muleshoe & Muleshoe & Sigmodon hispidus & Sigmodontinae & U54575 & 1989 & NEA & USA (Texas) \\
\hline 45 & Caño Delgadito & CanoDelgadito & Sigmodon alstoni & Sigmodontinae & AF000140 & 1130 & NEO & Venezuela (Portuguesa) \\
\hline
\end{tabular}




\begin{tabular}{|c|c|c|c|c|c|c|c|c|}
\hline 46 & Isla Vista & Isla Vista 1 & Microtus californicus & Arvicolinae & U19302 & 1720 & NEA & USA (California) \\
\hline 47 & Isla Vista & Isla Vista 2 & Microtus californicus & Arvicolinae & U31534 & 1720 & NEA & USA (California) \\
\hline 48 & Isla Vista & Isla Vista 3 & Microtus californicus & Arvicolinae & U31535 & 1302 & NEA & USA (California) \\
\hline 49 & Prospect Hill & ProspectHill1 & Microtus montanus & Arvicolinae & M34011 & 1675 & NEA & USA \\
\hline 50 & Prospect Hill & ProspectHill2 & Microtus montanus & Arvicolinae & Z49098 & 1675 & NEA & USA \\
\hline 51 & Prairie Vole & PrairieVole & Microtus ochrogaster & Arvicolinae & U19303 & 1722 & NEA & USA (?) \\
\hline 52 & Topografov & Topografov & Lemmus sibiricus & Arvicolinae & AJ011646 & 1951 & PAL & Russia FE (Taymyr) \\
\hline 53 & Khabarovsk & Khabarovsk & Microtus fortis & Arvicolinae & U35255 & 1845 & PAL & Russia FE (Khabarovsk) \\
\hline 54 & Vladivostock & Vladivostock & Microtus fortis & Arvicolinae & $\mathrm{AB} 011630$ & 1228 & PAL & Russia FE (Vladivostok) \\
\hline 55 & Tula-Germany 1 & TULV-Germany1 & Microtus arvalis & Arvicolinae & AF164093 & 1832 & PAL & Germany \\
\hline 56 & Tula-Germany2 & TULV-Germany2 & Microtus arvalis & Arvicolinae & AF289821 & 1828 & PAL & Germany \\
\hline 57 & Tula-Lodz & TULV-Lodz1 & Microtus arvalis & Arvicolinae & AF063892 & 1852 & PAL & Poland \\
\hline 58 & Tula-Lodz & TULV Lodz2 & Microtus arvalis & Arvicolinae & AF063897 & 1852 & PAL & Poland \\
\hline 59 & Tula-Moravia & TULV-Moravia & Microtus arvalis & Arvicolinae & Z69991 & 1831 & PAL & Moravia \\
\hline 60 & Tula-Slovakia & TULV-Slovakia1 & Microtus arvalis & Arvicolinae & AJ223601 & 1831 & PAL & Slovakia (Koziky) \\
\hline 61 & Tula-Slovakia & TULV-Slovakia2 & Microtus arvalis & Arvicolinae & $\mathrm{AJ} 223600$ & 1831 & PAL & Slovakia (Koziky) \\
\hline 62 & Tula-Slovakia & TULV-Slovakia3 & Microtus arvalis & Arvicolinae & Z48235 & 1831 & PAL & Slovakia (Malacky) \\
\hline 63 & Tula-Slovakia & TULV-Slovakia4 & Microtus arvalis & Arvicolinae & Y13979 & 1833 & PAL & Slovakia (Kosice) \\
\hline 64 & Tula-Slovakia & TULV-Slovakia5 & Microtus arvalis & Arvicolinae & Y13980 & 1832 & PAL & Slovakia (Kosice) \\
\hline 65 & Tula-Slovakia & TULV-Slovakia6 & Microtus arvalis & Arvicolinae & Z68191 & 1831 & PAL & Slovakia (Malacky) \\
\hline 66 & Tula-Russia & TULV-Russia & Microtus gregalis & Arvicolinae & Z30941 & 1847 & PAL & Russia (Tula) \\
\hline 67 & Tula-Serbia & TULV-Serbia & Microtus subterraneus & Arvicolinae & AF017659 & 1834 & PAL & Serbia $($ Cacac $)$ \\
\hline 68 & Puumala-Bashkortostan & PUUV-Bashkor & Clethrionomys glareolus & Arvicolinae & AF442613 & 1733 & PAL & Russia (Bashkortostan) \\
\hline 69 & Puumala-Belgium & PUUV-Belgium & Clethrionomys glareolus & Arvicolinae & $\mathrm{AJ} 277030$ & 1837 & PAL & Belgium (Thuin) \\
\hline 70 & Puumala-CG1820 & PUUV-CG1820 & Clethrionomys glareolus & Arvicolinae & M32750 & 1784 & PAL & $?$ \\
\hline 71 & Puumala-Denmark & PUUV-Denmark & Clethrionomys glareolus & Arvicolinae & AJ238791 & 1831 & PAL & Denmark \\
\hline 72 & Puumala-Evo & PUUV-Evo & Clethrionomys glareolus & Arvicolinae & Z30703 & 1832 & PAL & Finland \\
\hline 73 & Puumala-Kamiiso & HOKV-Kamiiso & Clethrionomys rufocanus & Arvicolinae & AB010730 & 1833 & PAL & Japan (Hokkaido) \\
\hline 74 & Puumala-Japan & HOKV-Japan & Clethrionomys rufocanus & Arvicolinae & AB010731 & 1833 & PAL & Japan (Tobetsu) \\
\hline
\end{tabular}




\begin{tabular}{|c|c|c|c|c|c|c|c|c|}
\hline 75 & Puumala-Karelia & PUUV-Karelia1 & Clethrionomys glareolus & Arvicolinae & $\mathrm{AJ} 238790$ & 1832 & PAL & Russia (Karelia, Gomselga) \\
\hline 76 & Puumala-Karelia & PUUV-Karelia2 & Clethrionomys glareolus & Arvicolinae & $\mathrm{AJ} 238788$ & 1828 & PAL & Russia (Karelia, Karhumaki) \\
\hline 77 & Puumala-Karelia & PUUV-Karelia3 & Clethrionomys glareolus & Arvicolinae & AJ238789 & 1830 & PAL & Russia (Karelia, Kolodozero) \\
\hline 78 & Puumala-Kazan & PUUV-Kazan & Clethrionomys glareolus & Arvicolinae & Z84204 & 1826 & PAL & Sweden? \\
\hline 79 & Puumala-Norway & PUUV-Norway1 & Clethrionomys glareolus & Arvicolinae & AJ223369 & 1849 & PAL & Norway (Eidsvoll) \\
\hline 80 & Puumala-Norway & PUUV-Norway3 & Clethrionomys glareolus & Arvicolinae & AJ223374 & 1828 & PAL & Norway (Mellansel) \\
\hline 81 & Puumala-Norway & PUUV-Norway4 & Clethrionomys glareolus & Arvicolinae & $\mathrm{AJ} 223375$ & 1829 & PAL & Norway (Mellansel) \\
\hline 82 & Puumala-Norway & PUUV-Norway5 & Clethrionomys glareolus & Arvicolinae & AJ223376 & 1871 & PAL & Norway (Solleftea) \\
\hline 83 & Puumala-Norway & PUUV-Norway6 & Clethrionomys glareolus & Arvicolinae & AJ223377 & 1882 & PAL & Norway (Solleftea) \\
\hline 84 & Puumala-Norway & PUUV-Norway7 & Clethrionomys glareolus & Arvicolinae & $\mathrm{AJ} 223380$ & 1827 & PAL & Norway (Tavelsjo) \\
\hline 85 & Puumala-Omsk & PUUV-Omsk1 & Clethrionomys glareolus & Arvicolinae & AF367067 & 1732 & PAL & Omsk-Russia (W Siberia) \\
\hline 86 & Puumala-Omsk & PUUV-Omsk2 & Clethrionomys glareolus & Arvicolinae & AF367068 & 1732 & PAL & Omsk-Russia (W Siberia) \\
\hline 87 & Puumala-Omsk & PUUV-Omsk3 & Clethrionomys glareolus & Arvicolinae & AF367069 & 1732 & PAL & Omsk-Russia (W Siberia) \\
\hline 88 & Puumala-Omsk & PUUV-Omsk4 & Clethrionomys glareolus & Arvicolinae & AF367070 & 1732 & PAL & Omsk-Russia (W Siberia) \\
\hline 89 & Puumala-Slovakia & PUUV-Slovakia & Clethrionomys glareolus & Arvicolinae & AF294652 & 1809 & PAL & Slovakia \\
\hline 90 & Puumala-Sotkamo & PUUV-Sotkamo & Clethrionomys glareolus & Arvicolinae & X61035 & 1830 & PAL & Finland (Sotkamo) \\
\hline 91 & Puumala-Udmurtia & PUUV-Udmurtia & Clethrionomys glareolus & Arvicolinae & Z21497 & 1827 & PAL & Finland (Udmurtia) \\
\hline 92 & Puumala-Vranica & PUUV-Vranica & Clethrionomys glareolus & Arvicolinae & U14137 & 1828 & PAL & Bosnia (Vranica) \\
\hline 93 & Thottapalayam & Thottalayam & Suncus murinus & Soricidae & AY526097 & 1530 & ORIENT & India (Thottalayam) \\
\hline
\end{tabular}

